\title{
Development of High Strength Fly Ash based Geopolymer Concrete with Alccofine
}

\author{
Bharat Bhushan Jindal ${ }^{1}$, Aniket Yadav ${ }^{2}$, \\ Abhishek Anand ${ }^{3}$, Akashdeep Badal $^{4}$ \\ ${ }^{1(}$ Research Scholar, IK Gujral Punjab Technical University, Kapurthala, Punjab, India) \\ 1, 2, 3, 4 (Department of Civil Engineering, M.M. University, Sadopur, Ambala, Haryana, India)
}

\begin{abstract}
The production of Ordinary Portland cement concrete causes havoc to the environment due to the emission of $\mathrm{CO}_{2}$ in the production of cement as well as mining which results in unrepairable damage to nature. Geopolymer concrete, a cement free concrete is an innovative green concrete in which binding properties are developed by the interaction of alkaline solutions with a source material that is rich in silica and alumina. Fly Ash, a by-product of coal obtained from the thermal power plant is rich in silica and alumina which on reacting with alkaline solution produces aluminosilicate gel that acts as the binding material for the concrete. Geopolymer concrete develop high compressive strength on heat curing promising to be an ecofriendly substitute for ordinary Portland cement concrete in some applications. This paper briefly put the light on the development of high strength geopolymer concrete with the help of Alccofine which is a micro fine GGBS based material.
\end{abstract}

Keywords - Geopolymer concrete, fly ash, Alccofine, compressive strength.

\section{INTRODUCTION}

Concrete is the second most widely used construction material next to water globally, owing to its better controllable structural properties, which significantly increased its demand in construction industry. Cement industry is manufacturing cement on a gigantic scale to fulfill this demand since it is the main constituent of concrete. The global production of cement is estimated at over 2.8 billion tones according to recent industry data [1]. It is estimated that, approximately $94.76 \times 10^{6}$ Joules is spent for each ton of cement production [2], resulting into carbon dioxide emission, estimated to be nearly 5 to $7 \%$ of the total production of carbon dioxide [3] which cautious the concrete industry to switch over from Portland cement to a greener alternative binder. The world earth summits held in 1992 and 1997 expressed its concern about the increased emission of greenhouse gases to the atmosphere. [4]. The concept of geopolymer concrete was forwarded by a French scientist Joseph Davidovits who proposed alkaline liquid as an activator to be used to react with some source material rich in silicon and aluminium, such as industry and agro waste products like fly ash or rice husk ash to produce geopolymer mortar which act as binder. India produced 163.56 MT of fly ash in 2012-2013 which is an environment threat to the public, so need of the hour is to dispose off it properly, which encourages the use of fly ash as an alternative to OPC based concrete. [5] So geopolymer concrete addresses the local environment as well as global warming issue due to the utilization of fly ash as well as controlling the production of $\mathrm{CO}_{2}$ in the production of geopolymer concrete. Compressive strength of concrete increases significantly on addition of a small quantity of Alccofine 1203 which is ground granulated blast furnace slag based micro fine material is used as admixture. [6] This paper puts forward an attempt to study the effect of Alccofine in developing high strength geopolymer concrete.

\section{EXPERIMENTAL PROGRAMME}

This paper is based on the experiments conducted on the formulation of fly ash based geopolymer concrete which conforms to the mix design of G35 geopolymer concrete proposed by Junaid et al [7]. Sharma C. and Jindal B.B. in their research paper that ambient curing of geopolymer concrete results into development of poor early compressive strength. [8] So heat curing method is adopted. Curing temperature plays an important role in geopolymerisation process which has very significant role in the setting and hardening of geopolymer concrete which provides high compressive strength [9]. It has been established that at higher temperatures the alumino- 
silicate phase in fly ash is highly activated so curing at elevated temperature between $60^{\circ} \mathrm{C}$ to $90^{\circ} \mathrm{C}$ provides higher early compressive strength [10]-[11]. Concentration of $\mathrm{NaOH}$ plays a significant role in the compressive strength of geopolymer concrete, at a concentration of $16 \mathrm{M}$ of $\mathrm{NaOH}$ higher compressive strength was observed as compare to $8 \mathrm{M}$ and $12 \mathrm{M}$ solution [12]. In this study $16 \mathrm{M} \mathrm{NaOH}$ solution was taken. The time elapsed between the end of casting of samples and the start of heat curing can be termed as rest period which significantly affects the compressive strength [13] so a rest period of $24 \mathrm{hrs}$ provided.

GPC samples are prepared with and without Alccofine as per mix proportion in Table 1, then given a rest period of 24 hours after casting followed by heat curing at $90^{\circ} \mathrm{C}$ for 72 hours in electric oven along with moulds as shown in fig 1 . Compressive strength of cubes is tested by power operated compression testing machine as shown in fig. 2.

The source material used was class $\mathrm{F}$ fly ash which was procured from Ultratech RMC plant Panchkula, Haryana. Alccofine 2013 was procured from Ambuja Cement Ltd Chandigarh. The coarse aggregate was procured from a locally available crusher, it comprised of $14 \mathrm{~mm}, 10 \mathrm{~mm}$ and $7 \mathrm{~mm}$ downgraded aggregate. The aggregate is washed, dried and it was lightly sprinkled with water to obtain the aggregate in SSD condition prior to use. The alkaline liquid comprised of sodium hydroxide and sodium silicate solution. The materials were procured from local market Ambala. Sodium hydroxide was procured in pellet form with $99 \%$ purity. Since the mixing of distilled water and sodium hydroxide is an exothermic reaction, the sodium hydroxide solution is prepared with distilled water one day in advance prior to the casting in order to allow the solution to cool down. Molarity of sodium silicate solution was kept as 16M. A superplasticizer (Galenium based), in the quantity of $2 \%$ of mass of fly ash was used to increase the workability. Sodium silicate solution was procured in solution form. Sodium hydroxide solution and sodium silicate are mixed along with the dose of super plasticizer thoroughly at least one hour in advance to mixing of ingredients of concrete.

Dry mixing of aggregates is done for 5 minutes followed by wet mixing for 10 minutes thoroughly to have uniform mixing which significantly affects the structural properties of concrete.

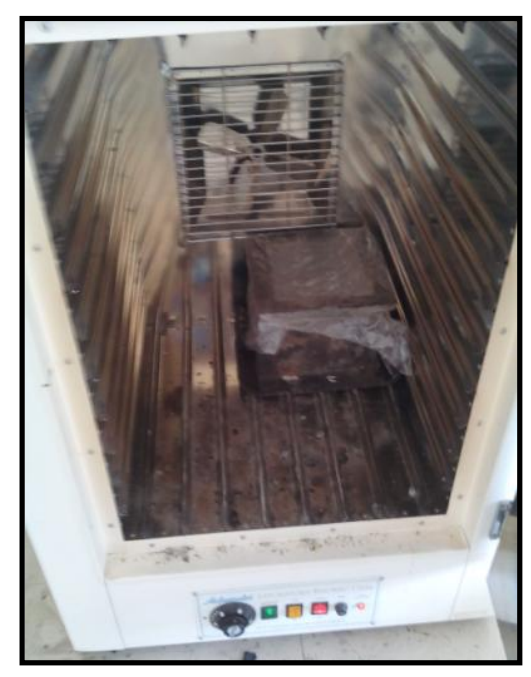

Fig. 1 GPC samples cured at $90^{\circ} \mathrm{C}$ in oven

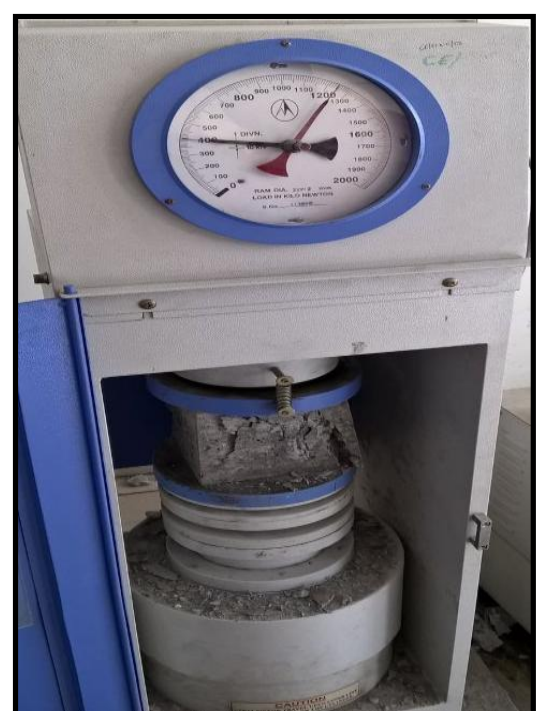

Fig. 2 Compression testing of samples 
Table I. Mix proportions (in $\mathrm{Kg}$ ) of GPC 35 per cubic meter of GPC

\begin{tabular}{|l|l|l|l|l|l|l|l|l|l|}
\hline $\begin{array}{l}\text { Mix } \\
\text { Designation }\end{array}$ & $\begin{array}{l}\text { Fly } \\
\text { Ash }\end{array}$ & $\begin{array}{l}\text { Coarse } \\
\text { Aggregates } \\
(14 \mathrm{~mm})\end{array}$ & $\begin{array}{l}\text { Coarse } \\
\text { Aggregates } \\
(10 \mathrm{~mm})\end{array}$ & $\begin{array}{l}\text { Coarse } \\
\text { Aggregates } \\
(7 \mathrm{~mm})\end{array}$ & $\begin{array}{l}\text { Fine } \\
\text { Aggregates }\end{array}$ & Alccofine & $\mathrm{NaOH}$ & $\mathrm{Na}_{2} \mathrm{SiO}_{3}$ & Water \\
\hline M1 & 400 & 565 & 445 & 255 & 540 & $0 \%$ & 52.58 & 131.45 & 27.07 \\
\hline M2 & 400 & 565 & 445 & 255 & 540 & $5 \%$ & 52.58 & 131.45 & 27.07 \\
\hline M3 & 400 & 565 & 445 & 255 & 540 & $10 \%$ & 52.58 & 131.45 & 27.07 \\
\hline
\end{tabular}

\section{RESULTS AND DISCUSSIONS}

Based on the experimental investigations carried out for G35 grade of geopolymer concrete following results for compressive strength have been obtained as in Table II.

Table II Compressive strength of geopolymer concrete in MPa

\begin{tabular}{|c|c|c|c|}
\hline \multirow{2}{*}{$\begin{array}{c}\text { GPC Mix } \\
\text { Designation }\end{array}$} & Description of mix & \multicolumn{2}{|c|}{ Compressive Strength on the age of } \\
\cline { 3 - 4 } & G35 with 0\% Alccofine & $32 \mathrm{MPa}$ & $\mathbf{2 8}$ Days \\
\hline Mix 1 & G35 with 5\% Alccofine & $39 \mathrm{MPa}$ & $44 \mathrm{MPa}$ \\
\hline Mix 2 & G35 with 10\% Alccofine & $52.5 \mathrm{MPa}$ & $73 \mathrm{MPa}$ \\
\hline Mix 3 & & & \\
\hline
\end{tabular}

Results shown in Table 2 point out the following observations:

i) Compressive strength of GPC without Alccofine at the age of 7 days is nearly same as expected for OPC based concrete after 28 days.

ii) Compressive strength has significantly increased on addition of Alccofine.

iii) High strength geopolymer concrete of $73 \mathrm{MPa}$ is achieved on $10 \%$ addition of Alccofine for a mix design of $35 \mathrm{MPa}$

\section{CONCLUSION}

1. Geopolymer concrete show high early compressive strength on heat curing which make it suitable for useful in pre casting industry.

2. Geopolymer concrete gain compressive strength at 7 days equivalent or higher than the ordinary Portland cement in 28 days.

3. Alccofine due to its micro fine structure significantly enhances the structural properties of GPC.

4. Alccofine increases compressive strength of G35 grade geopolymer concrete to nearly $75 \mathrm{MPa}$ after 28 days of age. 


\section{ACKNOWLEDGEMENT}

Authors acknowledge the Ultra Tech Ready Mix plant Panchkula and Ambuja Cement Ltd Chandigarh for providing required materials.

\section{REFERENCES}

[1] Cembureau “Cement in Cembureau Countries Statistics 2005- 2007”, http://www.cembureau.be.

[2] Davidovits, J. (1994). "High-Alkali Cements for 21st Century Concretes", ACI Special Publication, 144, 383-398.

[3] Mehta, P. K. 2001 "Reducing the Environmental Impact of Concrete", ACI Concrete Tech International 23(10): pp. 61-66

[4] Malhotra, V. M. (1999). "Making Concrete "Greener” With Fly Ash.” Concrete International, 21(5), 61-66.

[5] Central Electricity Authority. (2014). "Report on Fly ash generation at Coal/Lignite Based Thermal Power Stations and Its Utilization in The Country, For The Years 2011-12 And 2012-13”, Central Electricity Authority, Government of India, New Delhi.

[6] Patel et al, "Effect of Alccofine and Fly Ash Addition on the Durability of High Performance Concrete", IJSRD Vol. 1, Issue 3, 2013.

[7] Junaid M. et al, "A mix design procedure for low calcium alkali activated fly ash- based concretes" Journal of Construction and Building Materials March 2015.

[8] Sharma C., Jindal B.B., "Effect of variation of fly ash on the compressive strength of fly ash based Geopolymer Concrete" IOSR Journal of Mechanical and Civil Engineering (IOSR-JMCE) April 2015.

[9] B. V. Rangan, D. Hardjito, S. E. Wallah, and D. M. J. Sumajouw, "Studies on fly ash-based geopolymer concrete, Geopolymer: green chemistry and sustainable development solutions", Faculty of Engineering and Computing, Curtin University of Technology, GPO Box U 1987, Perth 6845, Australia, pp. 133-138

[10] F. Puertas, S. Martinez-Ramirez, A. Alonso, T. Vasquez, "Alkali activated fly ash/slag cements: strength behavior and hydration products", Cement and Concrete Research, 30 (10): 2000, pp. 1625-1632

[11] P. Chindaprasirt, T. Chareerat, V. Sirivivatnanon, "Workability and strength of coarse high calcium fly ash geopolymer", Cement \& Concrete Composites, 29 (3): 2007, pp. 224-229.

[12] Suresh.G. Patil, ManojKumar, "Factors influencing compressive strength of geopolymer concrete", IJRET 2013.

[13] Rangan BV. Concrete construction engineering handbook. $2^{\text {nd }}$ ed. New York : CRC Press; 2007. 